\title{
Cristianismo e a Renúncia de si no Último Foucault
}

[Christianity and the Self-Renunciation in the Late Foucault]

\author{
Rafael Siqueira Monteird
}

Resumo: O presente artigo analisou como o cristianismo produziu uma subjetividade por meio da qual o sujeito renunciou a si mesmo. Defendemos a hipótese de que esse modo de subjetivação cristã somente foi possível graças a duas características presentes na relação sujeito e verdade no cristianismo primitivo: a obrigatoriedade de confessar uma verdade de si e a imperfeição que caracteriza a natureza humana na antropologia cristã. Em outras palavras, a confissão da verdade de si tornou-se uma espécie de cura para os pecados oriundos da natureza imperfeita dos homens. Nesse duplo movimento que se iniciava por uma hermenêutica de si e findava na verbalização da verdade encontrada em seu próprio interior, o sujeito se enredou em uma malha de poder constituída por verdades confessadas que o levaram a renunciar a si mesmo.

Palavras-chave: Cristianismo. Renúncia de si. Verdade. Sujeito. Confissão.

\begin{abstract}
This article analyzed how Christianity produced a subjectivity through which the subject renounced himself. We defend the hypothesis that this mode of Christian subjectivation was only made possible due to two characteristics present in the relationship between subject and truth in early Christianity: the obligatoriness to confess a truth about oneself and the imperfection that characterizes human nature in Christian anthropology. In other words, the self-truth confession has become a kind of cure for sins arising from the imperfect nature of men. In this double movement which began with a hermeneutics of the self and ended with the verbalization of the truth found within one's own self, the subject became entangled in a mesh of power constituted by confessed truths that led him to renounce himself.
\end{abstract}

Keywords: Christianity. Self-renunciation. Truth. Subject. Confession.

*Professor da Secretaria de Educação do Estado do Pará (SEDUC/PA). Mestre em filosofia pela Universidade Federal do Pará (UFPA). E-mail: epistemephilo@gmail.com. ORCID: 


\section{Introdução}

O interesse de Michel Foucault pelo cristianismo se tornou mais evidente no período que nos habituamos chamar de último Foucault, no qual ele se voltou especificamente para a obrigatoriedade da verdade de si imposta pelo cristianismo. Segundo o filósofo francês, essa obrigatoriedade da verdade de si foi desenvolvida pelo cristianismo em dois eixos principais: práticas penitenciais, nos três primeiros séculos, e instituição monástica, nos séculos IV e V. Respectivamente, a verdade confessada através da dramaticidade do corpo e a verdade verbalizada em um formato de confissão a um diretor espiritual ou confessor.

Essa novidade que o cristianismo primitivo aportou para o ocidente culminou, segundo Foucault, na formação de uma subjetividade cristã para o mundo ocidental. Subjetividade que constituiu um sujeito obediente e capaz de renunciar a si mesmo em nome de uma verdade que ele crê ter encontrado, mas que exigiu quer o reconhecimento de sua natureza pecaminosa, quer a confissão de seus pecados.

Nessa perspectiva, o presente artigo analisou como o cristianismo produziu uma subjetividade por meio da qual o sujeito renunciou a si mesmo. Defendemos a hipótese de que esse modo de subjetivação cristã somente foi possível graças a duas características presentes na relação sujeito e verdade no cristianismo primitivo: a obrigatoriedade de confessar uma verdade de si e a imperfeição que caracteriza a natureza humana na antropologia cristã.

Nessa perspectiva, esse artigo terá quatro tópicos: o primeiro diz respeito à obrigação da verdade de si no cristianismo primitivo, o segundo e o terceiro, respectivamente, irão se debruçar sobre as duas principais formas de confessar a verdade de si nesse recorte histórico: exomologèse e exagóreusis; e no quarto tópico, voltaremo-nos para as consequências dessa maneira singular do sujeito se relacionar com a verdade no cristianismo.

\section{A obrigação da verdade de si no cristi- anismo primitivo}

O interesse de Michel Foucault pela religião cristã foi crescendo ao longo de sua trajetória intelectual. Foucault a abordou por diferentes ângulos 1 , desde as práticas de tratamento para doenças venéreas que incluíam a confissão

\footnotetext{
${ }^{1}$ Referências sugestivas ao ocidente oposto a um Oriente nietzschiano desde o prefácio à Folie et déraison (Loucura e desrazão) em 1961, diálogo com Georges Bataille, Maurice Blanchot ou Pierre Klossowski ao longo dos anos 1960, dossiês históricos da confissão (1975) e da pastoral cristã (1978) abertos pelos cursos no Collège de France e, sobretudo, o esboço várias vezes retomado do empreendimento, entre 1978 e 1984, de um grande livro sobre Confissões da carne: Foucault não cessou de se interessar pelo cristianismo (CHEVALIER, 2012, p. 45 ).

${ }^{2}$ Começa-se, naturalmente, com uma sangria, logo seguida por uma purgação; destina-se uma semana aos banhos, à razão de duas horas por dia, aproximadamente; purga-se outra vez e para encerrar esta primeira fase do tratamento impõe-se uma boa e completa
} 
como parte do tratamento, tratadas em sua História da Loucuran, até a obrigatoriedade da verdade de si, presente em seus escritos da década de 1980. É justamente nessas abordagens realizadas em múltiplas perspectivas que a confissão aparece como central em suas pesquisas sobre o cristianismo, incidindo profundamente sobre a relação sujeito e verdade no ocidente. Nesse sentido, Senellart (2012, p. 73) afirma que:

Se os ângulos de abordagem variam, a análise foucaultiana, ao contrário, segue um fio condutor muito constante, através da problemática geral da confissão, ou seja, da relação específica, na cultura cristã, que liga o sujeito a sua própria verdade, em vista de assegurar sua salvação.

$\mathrm{O}$ excerto acima nos mostra que quando tratamos do conceito "confissão" no cristianismo, a partir da ótica do último Foucault, concomitantemente tratamos da questão da verdade e da questão do sujeito. Porque o que se confessa na confissão cristã é uma verdade de si e quem confessa é um sujeito marcado ontologicamente pelo pecado, mas que deseja ardentemente a salvação.

Isso nos faz pensar que a abordagem do cristianismo realizada por Foucault esteja no interior de um projeto maior da história do sujeito ocidental ${ }^{3}$ empreendida por ele, sobretudo na década de 1980. Pois, como o próprio Foucault afirmou, algumas vezes, "busquei antes produzir uma história dos diferentes modos de subjetivação do ser humano em nossa cultura [...]. Assim, não é o poder, mas o sujeito, que constitui o tema geral de minha pesquisa " (FOUCAULT, 1994, p. 223, tradução nossa).

Assim, o cristianismo foi abordado por Foucault no intuito de descobrir o porquê do homem ocidental ser aquilo que ele é. Nesse processo histórico da construção do sujeito ocidental, o cristianismo foi um elemento fundamental no sentido de que, por meio de técnicas de si, ele infligiu a seus adeptos a obrigatoriedade da verdade de si, isto é, a obrigação de confessar quer através do corpo, quer através da voz. Tal obrigatoriedade culminou na constituição de um sujeito que renunciou a si mesmo, projetando-se, consequentemente, no interior de uma malha de poder cujos fios são constituídos de verdades confessadas.

Logo, o interesse de Foucault pelo

confissão. Podem começar então as fricções com mercúrio, toda a eficácia de que dispõem; prolongam-se por um mês, em cujo término duas purgações e uma sangria devem expulsar os últimos humores morbíficos. Concedem-se quinze dias de convalescença. Depois, após ter acertado as contas definitivamente com Deus, o paciente é declarado curado e mandado embora (FOUCAULT, 2019, p.86).

${ }^{3}$ Sobre a tese de que o interesse de Foucault pelo cristianismo esteja inserido na genealogia do sujeito ocidental, ver ALVES (2016), MANICKI (2012), SENELLAR (2012). 
cristianismo deve-se, possivelmente, à intuição do filósofo de que muitas respostas acerca do que nós somos encontravam-se no cristianismo primitivo. Pois foi nos primeiros séculos do cristianismo que a subjetividade do homem ocidental começou a ser delineada e, para Foucault, a subjetividade do homem ocidental é cristã.

Para a história da subjetividade no ocidente, a história do cristianismo é fundamental. No cristianismo, há um registro da verdade em que dois processos estão envolvidos: a iniciação na verdade e o exercício probatório da verdade. Foucault está ciente da natureza sem precedentes de seu trabalho quando embarca na história de "me diz quem tu és". Não se trata de apenas percorrer o caminho do sujeito para a verdade, mas como ele é obrigado a dizer quem ele é, dentro de uma trama de poderes, porque, se não, ele nunca percorrerá esse caminho: "o ser que é verdadeiro não se manifestará em ti" - sintetiza assim, Foucault, a vontade de verdade cristã em Do governo dos vivos
(1979-1980) - mais do que se tu manifestares a verdade do que és (SAUQUILLO, 2017, p. 386, tradução nossa)

Conforme Sauquillo, na citação acima, o cristianismo na história da subjetividade ocidental, além de ser um tema imprescindível para Foucault, também é um tema de extrema originalidade. A subjetividade cristã aparece como uma forma visceral do sujeito se relacionar com a verdade, se entendermos que a verdade que emana desse sujeito em forma de confissão é oriunda do que há de mais profundo em seu ser cristão, seu vínculo com Deus. Um Deus que só se manifestará em sua verdade se, por sua vez, o cristão manifestar a verdade do que ele mesmo é.

Foucault parece ter pesquisado profundamente o universo cultural cristão e provavelmente o conhecia muito bem, pois em seus escritos percebemos o mundo moral e teológico da religião cristã com seus ritos penitenciais e também as práticas monásticas. No curso de 1981, intitulado Malfazer, dizer verdadeiro, essa familiaridade com o cristianismo é bastante evidente. Ele abordou o cristianismo nesse curso como um modo de veridicção, isto é, um modo de dizer verdadeiro que atraves-

\footnotetext{
${ }^{4}$ Para la historia de la subjetividad en Occidente, es fundamental la historia del cristianismo. En el cristianismo se da un registro de la verdad donde se enganchan dos procesos: la iniciación en la verdad y el ejercicio probatorio de la verdad. Foucault es consciente del carácter inédito de su trabajo cuando emprende la historia del "dime quién eres". No se trata sólo de recorrer el camino del sujeto hacia la verdad, sino de cómo éste queda obligado a decir quién es, dentro de una trama de poderes, pues, si no, nunca recorrerá este camino: "el ser que es verdadero no se manifestará en ti - sintetiza así, Foucault, la voluntad de verdad cristiana en Du gouvernement des vivants (1979-1980) - más que si tú manifiestas la verdad que eres" (SAUQUILLO, 2017, p. 386).
} 
sou a história e marcou profundamente a cultura ocidental.

$\mathrm{O}$ aspecto teológico da antropologia cristã nos parece importante para a compreensão da leitura que Foucault faz do cristianismo primitivo no curso Malfazer, dizer verdadeiro. Pois, nesse curso, ele procurou compreender o modo de veridicção cristão a partir da prática da penitência nos três primeiros séculos e do exame de consciência e da direção espiritual nos IV e V séculos. Todas essas práticas são, para o cristianismo, instrumentos de salvação da alma e meios para que a natureza decaída do homem se erga diante de Deus.

Essas práticas cristãs foram estudadas por Foucault em seus escritos da década de 1980, sobretudo em Malfazer, dizer verdadeiro, mas também em Do governo dos vivos, em Subjetividade e verdade e no seu livro recém-publicado As confissões da carne. Nesse período, ele se debruçou em leituras variadas do cristianismo, como: escritos dos padres da Igreja, textos de cunho catequético, a história do monaquismo cristão, suas regras, suas práticas e seus modos de vida 5 .

No curso Malfazer, dizer verdadeiro, na aula de 29 de abril de 1981, Foucault analisou uma especificidade própria do cristianismo: a obrigação da verdade de si. Isto é, o cristão é obrigado a realizar por toda sua existência uma hermenêutica de si a fim de buscar no próprio interior sua verdade mais profunda. Nesse sentido, Foucault compreendeu essa obrigatoriedade da verdade de si como a característica mais fundamental do cristianismo, como podemos verificar a seguir:

Uma das características mais fundamentais do cristianismo é ter vinculado o indivíduo à obrigação de buscar em si mesmo a verdade do que ele é. $\mathrm{O}$ cristianismo vinculou o indivíduo à obrigação de busca, no fundo de si mesmo e a despeito de tudo o que poderia ocultar essa verdade, certo segredo, certo segredo cujo esclarecimento, cuja manifestação deve ter importância decisiva em sua caminhada para a salvação da alma (FOUCAULT, 2018b, p. 80).

À obrigação do dizer verdadeiro sobre si mesmo, Foucault chamou de veridicção. Esse conceito seria o resultado de um conjunto de técnicas que o cristianismo, se não descobriu, ao menos desenvolveu, como o exame de consciência, a direção espiritual e a penitência.

\footnotetext{
${ }^{5} \mathrm{~A}$ vida dos primeiros mosteiros era orientada por uma regra de vida. Um conjunto de normas que orientava as ações dos monges em diferentes situações do cotidiano: o trabalho, a oração, a alimentação, a caridade, a convivência entre os monges. Como exemplo concreto podemos citar no século V a regra de Santo Agostinho e no século VI a famosa regra de São Bento que guia até os dias atuais a vida dos monges beneditinos.
} 
A primeira técnica - exame de consciência - passava-se geralmente pouco antes do monge dormir. Tratava-se de uma retrospecção do dia, dos seus atos e de seus pensamentos. Essa técnica também era utilizada antes das direções espirituais e da confissão.

A segunda - direção espiritual - era a marca indelével da vitalícia condição de imperfeição e fraqueza diante do mal, que caracterizava os homens em geral e o monge em particular. Eles nunca poderiam estar prontos para caminharem sozinhos como sujeitos livres e soberanos. Por isso, submetiam-se às orientações de um diretor espiritual, ao qual confessavam seus desejos, suas más ações e os pensamentos que iam de encontro à vida cristã.

E a terceira técnica - penitência também caracterizada pela eterna condição de pecador, exigia do monge uma obediência incondicional cuja confissão era um importante meio para não se deixar enganar pelas inclinações do mal que lhe circundavam e estavam ontologicamente presentes em sua natureza humana. O olhar do diretor espiritual ou do confessor era a certeza de que o monge não se distanciaria do reto caminho. Pois todo comportamento não condizente com a vida de monge seria observado com mais nitidez por esse olhar externo.

Ao se interessar pelo cristianismo primitivo, ou mais precisamente pela obrigatoriedade da verdade de si, desenvolvida por meio de uma série de técnicas de si ou procedimentos cristãos, Foucault destacou que o cristianismo primitivo desenvolveu duas formas diferentes de produzir uma verdade de si mesmo nos cinco primeiros séculos: exomologèse e exagóreusis. A exomologèse pode ser definida como o conjunto de práticas e exercícios obrigatórios a todo e qualquer penitente que deseja se redimir de algum pecado através de uma confissão dramática do corpo. E a exagóreusis, por sua vez, é a confissão verbal da verdade de si no intuito de remissão de uma falta, mas, sobretudo, meio para uma vida de santidade desenvolvida no interior da vida monástica.

\section{A confissão como exomologèse no cris- tianismo primitivo dos séculos I a III}

$\mathrm{Na}$ aula do dia 29 de abril do ano de 1981 do curso Malfazer, dizer verdadeiro, Foucault abordou a questão da veridicção cristã. Para tal, ele se lançou em uma análise da penitência cristã dos primeiros séculos e que, portanto, pouco se assemelhava com a penitência que conhecemos hoje, a qual se delineou no século XII. Tratava-se de uma série de ritos e práticas cristãs que visavam oferecer uma segunda possibilidade de salvação da alma para aqueles que caíram em pecado após o batismo.

O problema da penitência no cristianismo primitivo era: 
quem é batizado não deve pecar mais; quem pecar deverá ser excluído da comunidade eclesiástica; apesar disso, haverá algum recurso para que o indivíduo seja reintegrado, já que seu pecado deveria tê-lo excluído, já que ele mesmo se excluiu da comunidade pela existência do pecado? Em outras palavras, a penitência é o problema do segundo batismo. Será possível ser batizado pela segunda vez? Ou existe a possibilidade de ser reintegrado por alguma coisa que não seja um segundo batismo? Esse é, digamos, o quadro geral no qual o problema se apresenta no segundo século (FOUCAULT, 2018b, p. 90).

Foi nesse contexto que Foucault tratou da exomológesis, porém ele não se deteve apenas a uma única definição desse conceito. Entre as várias definições ofertadas por ele escolhemos aquela que designaria a exomológesis como o conjunto dos passos que compunham as práticas penitenciais ou como o próprio Foucault descreveu em seu curso Malfazer, dizer verdadeiro, "a palavra exomológesis quer dizer ser penitente e levar vida de penitente, de que a vida de penitente é chamada de reconhecimento, confiteor, confissão" (FOUCAULT, 2018b p.95).
Entre os vários sentidos do conceito exomológesis atribuídos por Foucault nessa aula, sublinhamos a confissão e o reconhecimento, pois a nosso ver, eles descrevem com mais precisão o papel da prática penitencial nos três primeiros séculos do cristianismo. A exomológesis era uma forma de dizer a verdade sobre si mesmo, uma espécie de confissão dramática, mas não centrada na palavra, na confissão verbal, mas no corpo. No corpo que suplica, que chora, que sofre, que deseja veementemente o perdão.

Nessa perspectiva, Foucault, em uma conferência proferida na universidade de Grenoble, em maio de 1982, afirma que:

Obrigação de manifestar a verdade sobre si, é isso que faz parte do ritual da penitência: é a exomológesis, uma espécie de dramatização de si mesmo como pecador que se faz através de vestimentas, jejuns, provações, exclusão da comunidade, atitude suplicante na porta da igreja, etc.; dramatização de si, expressão dramática de si como pecador, pelo qual alguém se reconhece como pecador, mas sem passar - sem passar necessariamente, em todo caso, sem passar primeiramente e fundamentalmente - pela linguagem.

${ }^{6}$ Obligación de manifestar la verdad sobre sí, eso es lo que forma parte del ritual de la penitencia: es la exomológesis, una especie 


\section{É a exomológesis 6 (FOUCAULT, 2017, p. 121, tradução nossa).}

Em uma outra perspectiva, associando a exomologèse ao martírio em As confissões da carne, Foucault afirmou que por meio da exomologèse o penitente deveria testemunhar tal qual o mártir. Pois esse soube testemunhar sua fé e mostrar a verdade de si através de um corpo humilhado, torturado, morto. Não haveria confissão pública através do corpo mais eloquente do que o martírio.

Se a exomologèse é tão importante para a penitência, se ela faz parte da penitência nos ritos públicos e aparatosos, é que o penitente deve testemunhar como o mártir: Expressar seu arrependimento, mostrar a força que sua fé lhe dá e tornar manifesto que esse corpo que ele humilha não passa de poeira e morte, e que a verdadeira vida é em outro lugar ${ }^{7}$ (FOUCAULT, 2018a, p. 104, tradução nossa).

Evidentemente, nem todos precisavam passar pelo martírio de fato, mas a dimensão do autosacrifício contido no martírio devia estar presente nas práticas penitenciais. Nesse sentido, para conseguir o perdão, o cristão se submetia às práticas públicas de reconhecimento de sua condição de pecador, tal como ficar na frente da Igreja sem poder entrar, esperando o tão sonhado dia da reconciliação.

Percebe-se através dessa imagem dramática do homem pecador, que busca o perdão de Deus e da comunidade dos fiéis, o caráter de mortificação das práticas penitenciais. Isto é, trata-se de um autosacrifício, uma sorte de martírio cotidiano que tem como objetivo tornar público sua condição de pecador. "O penitente tem menos a "dizer verdadeiro" sobre o que ele fez do que "fazer verdadeiro", manifestando o que ele é" $\left.\right|^{8}$ (FOUCAULT, 2018a, p. 98).

Nesse sentido, na aula de 29 de abril de 1981 do curso Malfazer, dizer verdadeiro, Foucault expressa que:

\section{Veridicção e mortificação estão intimamente ligadas nessa prá- tica da penitência. Se a prática da penitência implica essa exo- mológesis, é porque, por meio dessa penitência, é preciso pri-}

\footnotetext{
de dramatización de sí mismo como pecador que se hace a través de la vestimenta, los ayunos, las pruebas, la exclusión de la comunidad, la actitud de suplicante a la puerta de la iglesia, etc.; dramatización de sí, expresión dramática de sí como pecador, por la cual uno se reconoce a sí mismo como pecador, pero sin pasar - sin pasar necesariamente, en todo caso, sin pasar primeramente y fundamentalmente - por el lenguaje. Es la exomológesis (FOUCAULT, 2017, p. 121).

${ }^{7} \mathrm{Si}$ l'exomologèse est si importante dans la pénitence, si elle fait corps avec celle-ci dans des rites publics et ostentatoires, c'est que le penitent doit témoigner comme le martyre: exprimer son repentir, montrer la force que lui donne sa foi et rendre manifeste que ce corps qu'il humilie n'est que poussière et mort, et que la vraie vie est ailleur (FOUCAULT, 2018a, p. 104).

8“(...) le penitente a moins à "dire vrai” sur ce qu'il a fait qu’à "faire vrai” en manifestant ce qu'il est” (FOUCAULT, 2018a, p. 98).
} 
meiro morrer para este mundo e depois provar, provar publicamente perante esse mesmo mundo, que se está pronto para sacrificá-lo, que se está pronto para sacrificar-se neste mundo, a fim de chegar àquele outro mundo. Ou seja, temse aí uma veridicção sobre si mesmo, um ato ritual por meio do qual se mostra a verdade de si mesmo, mas em relação com quê, em função de quê, em ligação com quê? Com a mortificação, ou seja, com o autosacrifício. Só produz a verdade sobre si mesmo quem é capaz de sacrificar-se. O sacrifício pela verdade sobre si mesmo, ou a verdade sobre si mesmo para o autosacrifício é o que está no cerne do rito da exomológesis penitencial (FOUCAULT, 2018b, p.97).

O excerto acima revela o martírio como o modelo que inspira as práticas penitenciais cristãs. O martírio enquanto autosacrifício, renúncia de si e confissão eloquente do corpo. Para se entender o porquê desse vínculo tão estreito entre martírio e veridicção é necessário levar em conta o contexto histórico dessas práticas penitenciais do século I ao III. Os primeiros cris- tãos eram perseguidos e muitas vezes, para se salvar, mentiam dizendo que não eram cristãos ou simplesmente a condição para não morrerem era negar seu mestre Jesus.

Essas dificuldades enfrentadas pelos cristãos geraram um grave problema nas primeiras comunidades. O que fazer com esses que negaram o nome de Jesus? As práticas penitenciais respondiam a esse problema. A solução encontrada foi a penitência enquanto exigência de uma verdade de si e como punição para o crime cometido. A verdade exigida do penitente e a punição a ele imposta eram a exigência mínima para ele voltar à Igreja dos mártires, daqueles que não titubearam diante da fé, pois "a obrigação do penitente de se manifestar, na verdade de sua condição de pecador e na autenticidade de sua penitência, baseia-se muito mais profundamente em sua relação com o martírio"' (FOUCAULT, 2018a, p.103, tradução nossa).

Como se vê, nesses três primeiros séculos a confissão como verbalização não aparece de forma significativa, embora Foucault a mencione em alguns momentos dos ritos batismais e penitenciais da Igreja primitiva no decorrer de seus cursos de 1980. Todavia, o corpo do pecador confessa a verdade de si através de uma liturgia do sofrimento e da dramaticidade do corpo hu-

\footnotetext{
${ }^{9}$ l'obligation pour le penitent de se manifester, dans la vérité de son état de pécheur et dans l'authenticité de sa pénitence, se fonde beaucoup plus profondément sur leur apport au martyre (FOUCAULT, 2018a, p.103).
} 
milhado, eis a grande marca desses três primeiros séculos.

\section{A confissão como exagóreusis no cris- tianismo primitivo do IV ao $\mathrm{V}$ século}

$\mathrm{Na}$ aula de 6 de maio de 1981 do curso Malfazer, dizer verdadeiro, sobretudo a partir dos textos de Cassiano e do Apophtegmata Patrum, Foucault analisou como a obrigatoriedade da verdade de si se desenvolveu nas instituições monásticas nos séculos IV e $\mathrm{V}$ em continuidade com as práticas penitenciais, mas trazendo uma novidade fundamental na relação que o sujeito mantém com a verdade no cristianismo primitivo. Não bastava somente produzir uma verdade de si e confessá-la em gestos corporais dramáticos, como ocorria nos três primeiros séculos, mas, sim, verbalizá-la a um outro encarregado de ouvir e orientar.

O monasticismo - justamente por causa da situação na qual estava e da institucionalização do ascetismo individual - considerará que essa purificação por mortificação e autoconhecimento só poderá ser realizada por meio de certa relação. Não simplesmente relação de si consigo - não simplesmente uma relação de conhecimento consigo ou uma relação de ascetismo e mortificação por meio de uma relação consigo mesmo -, mas também uma relação com o outro, uma relação com o mestre (FOUCAULT, 2018b, p. 109).

Essa necessidade do outro que escuta e orienta e a exigência da verbalização da verdade de si foram as duas principais características da exagóreusis. Nesse sentido, Foucault, na aula de 13 de maio de 1981, definiu o conceito exagóreusis como a "confissão permanente sobre si mesmo" (FOUCAULT, 2018b, p. 141). A vida do monge se tornou a confissão permanente de seus pensamentos e desejos a um outro indivíduo que, revestido de autoridade, recebeu o poder de governá-lo, não tanto pelo conteúdo dessa verdade, mas pelo ato em si de confessar.

Não era o conteúdo da verdade que interessava, mas o ato em si de confessar-se que trazia consigo um modo existência, que reconhecia a presença de uma autoridade a quem se devia, obrigatoriamente, produzir uma verdade de si mesmo como gesto de extrema obediência e submissão. Nesse sentido, Chevallier (2011, p. 135) dirá que:

O que une, na confissão religiosa, não é, portanto, o enunciado, mas unicamente a enunciação, não é a verdade dentro do seu conteúdo, mas unicamente o ato de produzir a ver- 
dade diante do outro. Alguém pode mesmo se perguntar si o ato de verdade finalmente não desaparece em benefício de um simples ato enunciativo que é antes de tudo reconhecimento de uma autoridade, obediente e submissa 10 .

Nasce um tipo de poder próprio ao cristianismo nesse momento, um poder pela verdade. $\mathrm{O}$ fundamento desse poder se encontrava na obediência total do indivíduo que confessava. Para Foucault, o modo de veridicção cristã visava fundamentalmente uma existência capaz de renunciar a si mesmo, o que gerava uma obediência absoluta a um outro. Como o cristianismo conseguiu tal feito? Na aula de 6 de maio de 1981, Foucault afirma que "esse estado de obediência [...] implica, evidentemente, duas coisas: primeiro, autoexame; segundo, o ato de dizer efetivamente, um ato verbal" (FOUCAULT, 2018b, p. 122).

Nessa mesma perspectiva, em As confissões da carne ele afirmou que:

Na forma geral de obediência e renúncia à vontade própria, o principal instrumento é a prática permanente de "exameconfissão", que no cristianismo oriental se chama exagóreusis: "cada um dos subordinados deve, por um lado, evitar esconder em seu coração qualquer movimento de sua alma; além disso, cuidado com o abandono de qualquer palavra sem controle e com a descoberta dos segredos do coração para os irmãos que receberam a missão de tratar os doentes com simpatia e compreensão [1" (FOUCAULT, 2018a, p. 133).

Como podemos observar, a construção da subjetividade cristã, fundamentada na obediência e na renúncia de si, desenvolveu-se a partir de duas técnicas de si - exame e confissão - em vista de um objetivo comum, qual seja a constituição de um sujeito obediente e capaz de renunciar a si mesmo. Em outras palavras, a vida monástica exigiu do monge o exame completo de sua vida e a confissão a um outro como um gesto de obediência e de renúncia de suas próprias vontades.

Podemos observar esse processo de

\footnotetext{
${ }^{10} \mathrm{Ce}$ qui lie, dans l'aveux religieux, n'est donc pas l'énoncé mais la seule énonciation ; non pas la vérité dans son contenu, mais le seul acte de produire la vérité devant autrui. On peut même se demander si l'acte de verité ne s'efface pas finalement au profit d'un simples acte énonciatif qui est d'abord reconnaissance d'une autorité, obéissance et soumission (CHEVALLIER, 2011, p. 135).

${ }^{11}$ Dans la forme générale de l'obéissance et de la renonciation à la volonté propre, la direction a pour instrument majeur la pratique permanente de "l'examen-aveux", ce que, dans le christianisme oriental, on appelle l'exagoreusis: "Chacun des subordonnés doit d'une part éviter de tenir caché dans son for intérieur aucun mouvement de son âme; d'outre part se garder de lâcher une parole quelconque sans controle et découvrir les secrets du coeur à ceux des frères qui ont reçu la mission de soigner les malades avec sympathie et compréhension" (FOUCAULT, 2018a, p. 133).
} 
formação da subjetividade cristã no ocidente nas análises de Foucault sobre a relação mestre e discípulo na antiguidade e que o cristianismo, de alguma forma, integrou em seu universo religioso ${ }^{12}$. Essa relação mestre e discípulo foi assumida pelo cristianismo na confissão, na direção espiritual, na relação superior e subordinado, assim como no contexto da vida monástica do monge mais experiente em relação ao noviço. Porém, Foucault deixa claro que diferentemente do que acontecia na filosofia antiga, na medida em que o indivíduo se aprofundava nesse caminho religioso, ele era enredado por uma dependência vitalícia em relação a outrem.

A queda de quem está bem avançado no caminho da santidade, essa queda é sempre possível desde que ele não admita, que deixe de admitir a possibilidade ou a obrigação de ser orientado, a partir do momento em que passa a ser ou quer ser mestre de si mesmo. Portanto, não há testemunho de orientação instituída para todos até o fim da vida, mas encontramos claramente o princípio de que a orientação não pode ser provisória, de que há, em todo caso, uma necessidade fundamental, contínua e permanente de orientação para toda alma (FOUCAULT, 2018b, p. 116).

É justamente nessa perspectiva de dependência perpétua que se encontra uma grande diferença entre as práticas de orientação da filosofia antiga e práticas de orientação cristã. Pois, para os antigos, "tratava-se de ser guiado até tornar-se sóphos, até torna-se sábio. Portanto, esta é a primeira característica: havia um objetivo, um objetivo preciso; por conseguinte, era uma orientação temporária" (FOUCAULT, 2018b, p. 113).

Nessa mesma perspectiva de ruptura na relação entre mestre e discípulo na filosofia antiga e na instituição monástica, podemos mencionar o papel do mestre em ambos os casos. Do lado da filosofia, a fama de inteligência e sabedoria que os mestres da filosofia deveriam gozar eram critérios imprescindíveis. Esses mestres só poderiam guiar alguém se fossem capazes de fazê-lo, capazes de transmitir valores, ensinamentos que guiassem suas condutas na vida social e privada, fazendo-os mestres de si mesmos e, portanto, capazes de conduzir livremente suas vidas.

Por fim, o último ponto, que resume todos os outros: é que,

\footnotetext{
${ }^{12} \mathrm{Na}$ aula de 6 de maio de 1981, Foucault deixa claro que a relação cristianismo e filosofia se dá na superfície, mas que difere em sua essência. Isto é, embora o cristianismo herde algumas práticas da filosofia antiga e as integre em seu universo religioso, ele as modifica inteiramente em seu significado originário.
} 
finalmente - aprendido esse código, interiorizada essa regra de comportamento graças à competência daquele que guiava, porque ele sabia -, o indivíduo que não sabia, o indivíduo que era guiado, tornava-se finalmente capaz de prescindir de mestre; e podia prescindir de mestre porque se tornava mestre. A operação de guiar consistia essencialmente numa espécie de substituição de mestria: aceitava-se a mestria do outro para poder garantir a própria mestria sobre si mesmo e por si mesmo (FOUCAULT, 2018b, p. 113).

Do lado das práticas monásticas, estas se encontravam no outro extremo, o monge não precisava ser dotado de grandes virtudes, inteligência ou sabedoria, mas somente revestido de uma autoridade para guiar bem ou mal o seu orientando. Pois, "o que faz progredir na vida, na vida da santidade, o que, por conseguinte, possibilita percorrer o caminho que deve levar à vida e à verdade é o fato puro de obedecer, seja qual for a ordem e seja qual for o mestre" (FOUCAULT, 2018b, p. 117).

Para Foucault, essa relação perpétua de escuta e obediência se dá através do cultivo de três virtudes cristãs: humildade, obediência e submissão. Humildade, porque devemos obedecer a todos; obediência, porque nunca devemos resistir a uma ordem dada; submissão, porque tudo o que fazemos deve ter a permissão de um superior. Todavia, para se chegar ao ápice da humildade, da obediência e da submissão é preciso falar, verbalizar, confessar os mais íntimos segredos.

O que está por detrás dessa perpétua relação de obediência desenvolvida pelo cristianismo? Por que a exigência de verbalizar a verdade de si mesmo? Mais uma vez a teologia e a antropologia cristã têm um papel importante nessa prática de veridicção específica ao cristianismo. Diz respeito ao fato de que o monge, o homem, está sempre em perigo de cair em tentação e a qualquer momento se perder em seu caminho de santidade. Logo, essa dependência da confissão a outrem, da verbalização dos desejos mais secretos do pensamento a um superior, explica-se pela natureza humana ontologicamente marcada pelo mal e sempre sujeita à queda.

Nesse sentido, Foucault (2018b, p.116) afirma que:

O que está em jogo em tudo isso é a ideia de um estado de perfeição. Não há estado de perfeição para o monge cristão, a despeito do que possam ter tido certos filósofos ou certas escolas de filosofia antiga. Não há estado de perfeição, digam o que disserem certos gnósticos ou dualistas. É isso o que se afirma e exemplifica no princípio da ori- 
entabilidade, digamos, ou no princípio de que deve sempre haver uma relação possível de orientação ao longo de toda a existência de um indivíduo.

Podemos perceber, então, que para Foucault não há perfeição humana na antropologia cristã, o homem é sempre frágil diante de si mesmo e do mal. Sua inclinação ao mal pode se manifestar mesmo onde ele pensa que sua ação o eleva a Deus. Por isso, havia necessidade de alguém para guiá-lo por toda sua existência, pois, sozinho, ele facilmente seria enganado por seu orgulho ou vaidade, e até mesmo pelo próprio demônio que quer sempre vê-lo sucumbir em sua estrutura interna de desejo.

Essa orientação permanente do monge se efetuava na prática monástica através da confissão dos pecados, dos pensamentos e dos desejos mais íntimos. Nada poderia ser escondido, a vida do monge deveria ser transparente como um vidro que deixa o sol da verdade traspassá-lo, purificando-o de dentro para fora e dando-lhe força para prosseguir em seu caminho de santidade.

Essa relação entre mestre e discípulo por meio da confissão, da exposição da verdade de si, entre monge e diretor de consciência, foi fundamental na vida monástica. Todavia, essa relação não ficou enclausurada nos mosteiros dos séculos IV e V, ao contrário, ganhou o mundo ocidental, constituiu um tipo de sujeito submisso, confessante, envolvido por uma teia de poder, cujos fios que o compõe são verdades construídas e encarnadas em sua existência.

Desse modo, a confissão cristã se integrou ao Estado e em suas instituições médicas e jurídicas. Obrigou-nos a confessar nossos hábitos alimentares, nossos costumes cotidianos, nossa vida sexual, nossos medos e desejos, nossas doenças, nossos crimes. O diretor de consciência ou o confessor deu espaço para o psiquiatra, o psicanalista, o psicólogo, o juiz e o delegado. Somos, portanto, herdeiros dos mosteiros do cristianismo primitivo no que concerne à exigência de confessarmos uma verdade de nós mesmos.

As práticas de veridicção sobre si mesmo, ou como, no monasticismo, o dizer verdadeiro sobre si mesmo se tornou um elemento absolutamente fundamental, essencial dessa vida e acabou sendo, com uma forma absolutamente nova, injetado, enxertado, implantado na cultura ocidental. A partir daí, essa prática da confissão, essa tecnologia complexa de veridicção sobre si mesmo, terá um sucesso considerável (FOUCAULT, 2018b, p. 110).

Portanto, quer na penitência do século I ao III, quer na verbalização de desejos, pensamentos e pecados na insti- 
tuição monástica nos séculos IV e V, há uma exigência da verdade de si. Uma verdade que nasce do processo de culpabilização por uma infração cometida e que constitui esse homem pecador em um sujeito confessante e dependente. Consequentemente, o sujeito que se constitui nesse processo de subjetivação cristã é empurrado cada vez mais para uma relação de poder.

\section{A subjetividade cristã do homem oci- dental}

As técnicas de si ou os procedimentos cristãos desenvolvidos ao longo dos cinco primeiros séculos da era cristã permitiram ao cristianismo governar seu rebanho. Por meio da exomologèse e da exagóreusis, o cristianismo desenvolveu uma espécie de método de governo que, como mater et magistra ${ }^{13}$ ensinou ao ocidente a como governar os homens por meio da verdade. Temos a impressão de que, em Foucault, a obrigação de dizer a verdade de si mesmo, desenvolvida pelo cristianismo, produziu uma relação de poder.

Nesse sentido, Sauquillo afirma que o cristianismo primitivo ofereceu as bases do poder moderno para o mundo ocidental:
O cristianismo para Foucault, compreende as formas arcaicas do poder moderno. Ao envolver o corpo na alma ou na personalidade, o cristianismo garante que sua identidade seja estabelecida e corrigida continuamente. $\mathrm{O}$ poder disciplinar no século XIX é uma secularização do triângulo cristão composta da obediência absoluta, exame permanente e confissão exaustiva dos desejos'14 (SAUQUILLO, 2017, p. 359, tradução nossa).

Esse triângulo mencionado por Sauquillo possivelmente não é equilátero, pois a confissão ganha um maior destaque no sentido de que ela se apresenta como meio e fim das outras duas técnicas de si. A confissão seria o resultado natural do exame permanente da consciência na vida monástica e o meio necessário para se chegar à obediência absoluta, uma vez que a rememoração dos erros cometidos durante a jornada precisavam ser verbalizados em um diálogo com o superior; e todo esse processo da verbalização da verdade de si objetivava em última instância a constituição de um monge obediente e capaz

\footnotetext{
${ }^{13}$ Latim: "mãe e mestra".

${ }^{14} \mathrm{El}$ cristianismo para Foucault, comprende las formas arcaicas del poder moderno. Al encerrar el cuerpo en alma o en la personalidad, el cristianismo se asegura establecer su identidad y corregirlo continuamente. El poder disciplinario del siglo XIX es una secularización del triángulo cristiano compuesto de obediencia absoluta, examen permanente de uno mismo y confesión exhaustiva de los deseos (SAUQUILLO, 2017, p. 359).
} 
de renunciar toda e qualquer autonomia.

O conjunto dessas técnicas de si, sobretudo, a confissão, tornaram possível a aparição de uma subjetividade cristã para o homem ocidental. Subjetividade que possibilitou a constituição de um sujeito, cuja identidade foi marcada pela sujeira do pecado e pela obediência absoluta. Alguém que deveria ser sempre orientado, haja vista que estava inclinado à queda e ontologicamente marcado pela imperfeição.

Ao produzir uma identidade de um sujeito imperfeito e sempre suscetível às forças do mal graças a sua condição ontológica de ser pecador, criou-se concomitantemente a necessidade de salvação ${ }^{15}$. Isto é, Deus está sempre disposto a estender a mão àqueles que caíram no pecado. É justamente nessa tensão entre imperfeição e necessidade de salvação no seio do cristianismo ${ }^{16}$ que possivelmente o poder pela verdade se produziu.

A penitência cristã, a direção de consciência perpétua, a confissão dos desejos, enfim, todas as técnicas de si que colocaram em cena uma relação de poder vertical, só foi possível, a nosso ver, quando o indivíduo se aceitou como um ser imperfeito, suscetível às investidas do mal e exposto a cair na animalidade dos instintos. Somente assim o cristianismo conseguiu que o sujeito livremente produzisse uma verdade de si, fosse governado por essa verdade e, mais do que tudo, disposto a renunciar a si mesmo 17 ,

A construção da subjetividade cristã foi evidentemente um processo que começou no século I, mas é na instituição monástica que encontramos um capítulo fundamental da genealogia do sujeito ocidental. A história da constituição do sujeito que renunciou a si mesmo começou nos primeiros passos da vida de monge. A estrutura hierárquica da Igreja e sua forma de regime monárquico contribuiu para imprimir nos candidatos à vida monástica a obediência completa e a exclusão de toda e qualquer vontade própria. O superior ou o abade ditavam as regras a serem seguidas, buscando incutir nos noviços a ideia de que é renunciando a si mesmo que eles encontrariam a vida plena em Deus.

Nesse sentido, na aula de 13 de maio de 1981 do curso Malfazer, dizer verdadeiro, Foucault afirma que:

Trata-se de fato, nessa exagóreusis, de autodestruir-se, de renunciar a si mesmo, renúncia que de algum modo acaba

\footnotetext{
${ }^{15}$ Nesse viés, Foucault, na aula de 26 de março de 1980 do curso Do governo dos vivos, afirma: Como vocês estão vendo, é sempre esse problema da perfeição e da necessidade ou, em todo caso, do objetivo que a Igreja cristã se deu contra um certo número de suas tendências internas ou contra um certo número de suas proximidades, esse esforço que ela fez para distinguir a economia da salvação da exigência de perfeição (FOUCAULT, 2018c, 265).

${ }^{16}$ Para um maior esclarecimento da relação imperfeição e salvação no cristianismo, ver Chevallier (2012).

17 “Aquele que acha a sua vida, a perderá, mas quem perde sua vida por causa de mim, a achará” (Mt, 10, 39).
} 
tendo dois papéis ou estando em duas posições simultâneas [...]. Por um lado, se quero mesmo me conhecer, se quero exercer esse controle tão necessário sobre mim, preciso renunciar a qualquer vontade autônoma, qualquer vontade que seja minha; preciso submeterme ao outro e dar como penhor de minha submissão ao outro o fato de que lhe digo tudo o que penso. E, graças a isso, ao cabo desse trabalho permanente e como efeito dele, inteiramente submisso à vontade do outro, tendo purificado meu coração de todos esses pensamentos móveis que o perturbam, vou poder abrir-me para Deus e não ter outra vontade que não seja a vontade de Deus (FOUCAULT, 2018b, p. 143).

Nessa mesma perspectiva, Foucault afirmou no curso Do governo dos vivos, na aula de 26 de março de 1980, que:

O primeiro imperativo era ensinar os noviços a vencer sua vontade, e os ensinavam a ven- cer sua vontade impondo-lhe um regime de obediência completo, exaustivo e permanente. Tratava-se, para eles, de obedecer sem cessar as ordens que podiam lhes dar, e aconselhavase aos que lhes davam ordens para fazer de sorte que estas fossem o mais possível contrárias às suas inclinações. Graças a isso, os noviços deviam chegar àquela renúncia de si que tem o nome de humildade (FOUCAULT, 2018c, 261).

Para chegar a esse estado de humildade ou renúncia de si mesmo o monge precisava de um olhar externo que enxergasse com mais clareza sua vida e seu comportamento. Um diretor de consciência, um confessor, um superior que lhe guiasse e alertasse acerca de suas vaidades e orgulhos. E, como foi mencionado anteriormente, essa missão de escutar e conduzir tinha como principal instrumento duas técnicas de si: o exame de consciência e a confissão.

Foucault observou que a matéria prima do dueto exame-confissão é o pensamento. Pensamentos eróticos, de glória e poder deveriam ser presos pelo

\footnotetext{
${ }^{18} \mathrm{Na}$ aula de 26 de março de 1980, Foucault explicou o porquê do cuidado em examinar o pensamento em sua atualidade conforme podemos observar a seguir: O exame deve centrar-se na atualidade do pensamento e não, retrospectivamente, no que foi feito. Trata-se de aprender o pensamento no momento em que começa a pensar, de apreender na raiz, quando estamos pensando no que pensamos. No sentido estrito, o exame é um exame de passagem, um exame de passagem na atualidade e que tem por função o quê? Exercer uma triagem, exercer [o que, precisamente, era chamado de] discriminatio. Não se trata portanto de medir a posteriori os atos para saber se são bons ou ruins, mas de aprender os pensamentos no exato momento em que se apresentaram, depois procurar o mais depressa possível, imediatamente, separar os que podemos acolher em nossa consciência e os que teremos de repelir, expulsar da nossa consciência (FOUCAULT, 2018c, p. 272).
} 
exame de consciência no ato mesmo do pensamento ${ }^{18}$, Deixá-los crescer em seu interior poderia se tornar um ato demasiado perigoso, pois aquele que menospreza as pequenas coisas, pouco a pouco, fomentaria sua própria destruição $0^{19}$. Para evitar esse processo paulatino de decadência provocado pela negligência das pequenas coisas, o mosteiro passou a exigir do monge não somente o exame de seus pensamentos e posteriormente sua confissão, mas exigiu também a apreensão do pensamento no ato mesmo de seu surgimento.

Após essas reflexões, constatamos que é através de um exame constante de si mesmo, na atualidade de seu pensamento, que o monge descobriria suas fragilidades. E, uma vez identificadas suas fraquezas, era necessário partilhar sua descoberta a um diretor de consciência, confessor ou superior, ou seja, a alguém incumbido de lhe orientar. Todo esse processo de exame da sua própria vida e da obrigação de verbalizá-lo em forma de confissão a um outro, culminaria em uma obediência total do monge e em um estado de humildade que não seria outra coisa senão a renúncia de si mesmo.

Nessa perspectiva, podemos constatar que Foucault, ao analisar a obrigatoriedade da verdade de si no cristianismo primitivo, identificou a forma- ção de um modo de subjetivação, que constituiu um sujeito que renunciou a si mesmo. Um sujeito cuja obediência eliminou qualquer satisfação pessoal; a vontade própria não mais existe e o único horizonte é a vontade de Deus na vontade do superior.

Renunciar a si mesmo é abrir mão de sua liberdade, gerando, assim, uma relação de dominação, pois o "sujeito renuncia a si mesmo e obedece indefinidamente ao outro" (GROS, 2004, p.17, tradução nossa) ${ }^{20}$. Uma relação de poder na qual quem confessa a verdade de si deve obedecer sem limites. Esse gesto de extrema radicalidade de obediência só encontrou sentido quando o cristão encontrou a verdade por excelência, Deus. Essa verdade só poderia ser alcançada através de um longo processo no qual a verdade de si mesmo, em forma de confissão, tornou-se uma exigência fundamental e incontornável.

\section{Conclusão}

Foucault não procurava compreender o cristianismo na perspectiva da fé, seu olhar era de um ateu, um hermeneuta ateu do cristianismo. Mas há algo de comum entre Foucault e os teólogos, ambos querem pensar o tempo presente servindo-se do passado. Foucault se voltou para os primeiros séculos do

\footnotetext{
${ }^{19}$ O que menospreza o pouco aos poucos cairá na miséria (Eclo, 19,1).

${ }^{20}$ Sujet donc de la mort à soi-même et de l'obéissance indéfinie à l'Autre (GROS, 2004, p.7).
} 
cristianismo para procurar a genealogia do sujeito ocidental. Pois, para ele a subjetividade do homem ocidental é cristã.

Nessa busca, Foucault constatou a importância da confissão na subjetivação cristã. $\mathrm{O}$ ato de confessar-se, mais do que a confissão em si, engendrou um poder próprio ao cristianismo, um controle dos indivíduos por meio da verdade que esses produziam de si mesmos. Um poder que impeliu o sujeito cristão a renunciar a si mesmo. Através da confissão do corpo que se arrepende e da voz que admite os seus pecados o cristianismo governou por meio da verdade.

O cristianismo, então, aparece como a tábua de salvação para esse sujeito inclinado ao mal. Deixa-se governar pela verdade de si; verdade que o identifica essencialmente como pecador e incapaz de ser mestre de si. Por isso, deixa-se conduzir por outrem durante toda sua existência, nunca está pronto para tomar suas próprias decisões, o mal está sempre lhe rodeando e pronto a lhe fa- zer sucumbir em meio aos seus infinitos desejos.

Teríamos, portanto, diante de nós, uma crítica ao cristianismo que talvez esteja na esteira dos grandes críticos da religião em geral e do cristianismo em particular? Possivelmente não, embora concordamos que seja possível retirar do pensamento de Foucault uma crítica ao cristianismo, no sentido de que o cristianismo criou um modo de governar pela verdade. Todavia, estamos bem distantes de pensadores como Marx, Nietsche e Freud para os quais a religião foi respectivamente ópio, ressentimento e doença.

Portanto, ao se debruçar sobre o cristianismo primitivo, Foucault buscou compreender a subjetividade do homem ocidental. Essa subjetivação cristã que marcou profundamente o homem ocidental possuía dois pilares: a exomologèse e a exagóreusis. Foi sobre esses dois fundamentos que o cristianismo interpelou o sujeito a renunciar a si mesmo.

\section{Referências}

ALVES, A.S. Marco. "Cristianismo e racionalidade política moderna em Michel Foucault". Revista do Departamento de Filosofias e Métodos Universidade Federal de São João del Rei, São João del Rei, 2016/2, n.17, pp. 76-88. Disponível em [https://ufsj.edu.br/revistaestudosfilosoficos/revista_no_17.php]: acessado em [14/06/2019].

CHEVALLIER, Philippe. Michel Foucault et le christianisme. ENS ÉDITIONS: Lyon, 2011.

. O cristianismo como confissão em Michel Foucault. Tradução de Pedro de Souza e Maria José Werner Salles. In:

CANDIOTTO, C.; SOUZA, P. (Orgs). Foucault e o cristianismo. Autêntica: Belo Horizonte, 2012.

FOUCAULT, Michel. Dits et écris, IV, Paris: Gallimard, 1994.

. La parrêsía. Tradução de Jorge Álvarez Yágüez. Madrid: Biblioteca Nueva, 2017.

. Les aveux de la chair. Paris: Gallimard, 2018 a.

Malfazer, dizer verdadeiro. Tradução de Ivone C. Benedetti. São Paulo: WMF Martins Fontes, $2018 \mathrm{~b}$.

. Do governo dos vivos. Tradução de Eduardo Brandão. São Paulo: WMF Martins Fontes, $2018 \mathrm{c}$.

. História da loucura. Tradução de José Teixeira Coelho Neto. São Paulo: Perspectiva, 2019. 
GROS, Frédéric. «Michel Foucault, une philosophie de la vérité ». In : FOUCAULT, Michel. Philosophie : anthologie. Anthologie établie et présentée par Frédéric Gros et Arnold I. Davidson. Paris: Gallimard, 2004.

MANICKI, Anthony. Técnicas de si e subjetivação no cristianismo primitivo: uma leitura do curso Do governo dos vivos. Tradução de Pedro de Souza. In: CANDIOTTO, C.; SOUZA, P. (Orgs). Foucault e o cristianismo. Autêntica: Belo Horizonte, 2012.

SAUQUILLO, Julián. Michel Foucault: Poder, saber y Subjetivación. Madrid: Alianza Editorial, 2017.

SENELLART, Michel. Verdade e subjetividade: uma outra história do cristianismo. Tradução de Cesar Candiotto e Pedro de Souza. In: CANDIOTTO, C.; SOUZA, P. (Orgs). Foucault e o cristianismo. Autêntica: Belo Horizonte, 2012.

Recebido: 25/05/2020

Aprovado: $14 / 12 / 2020$

Publicado: 31/01/2021 